\title{
Myoclonus as a late manifestation of West Nile disease
}

\author{
Satish Maharaj, ${ }^{1}$ Karan Seegobin, ${ }^{1}$ Belinda Bajric, ${ }^{1}$ Simone Chang ${ }^{2}$
}

\section{- Additional material is published online only. To view please visit the journal online (http://dx.doi.org/10.1136/ bcr-2017-223019). \\ ${ }^{1}$ Internal Medicine, University of Florida College of Medicine- Jacksonville, Jacksonville, Florida, USA \\ ${ }^{2}$ University of Miami Miller School of Medicine, Jackson Memorial Hospital, Miami, Florida, USA}

Correspondence to Dr Satish Maharaj, satish.maharaj@jax.ufl.edu

Accepted 3 November 2017

\section{DESCRIPTION}

A 68-year-old man presented with rhythmic shaking of right-sided extremities that occurred several times per day. The patient appeared confused with incoherent speech. His medical history was significant for West Nile fever diagnosed 8 weeks prior and managed supportively. During that admission, there had been extensive testing that was negative for Human T-Lymphotropic Virus (HTLV), HIV, syphilis or antinuclear antibodies. On examination, there was involuntary myoclonic jerking of the left face, neck and arm (online supplementary video 1). MRI of the brain was notable for leukoaraiosis (figure 1).

Electroencephalography (EEG) showed continuous generalised slowing, suggestive of a moderate diffuse encephalopathy. There was no evidence of electrographic seizures or epileptiform activity. Testing of the blood and cerebrospinal fluid (CSF) did not show any signs of meningitis. CSF culture and testing for herpes simplex virus were negative, as was MRI of the entire spinal cord. Supportive treatment of myoclonus included using baclofen $10 \mathrm{mg}$ three times daily and intermittent boluses of lorazepam. A trial of levetiracetam $750 \mathrm{mg}$ twice daily was also attempted but did not result in significant change.

After 5 days, there was a marked reduction in myoclonic jerking, but it was still evident (online supplementary video 2). By day 7 , there was resolution of myoclonic activity and the patient was now able to follow simple commands and talk, but he appeared to now have a flaccid paralysis of the left arm. On day 9 , the patient began to move the left arm, but there was now increased tone and cogwheel rigidity of the right arm. By day 11, this resolved. Repeat EEG during the episode of flaccid paralysis showed no evidence of electrographic seizures or epileptiform activity. During this time, the patient had much improved mentation

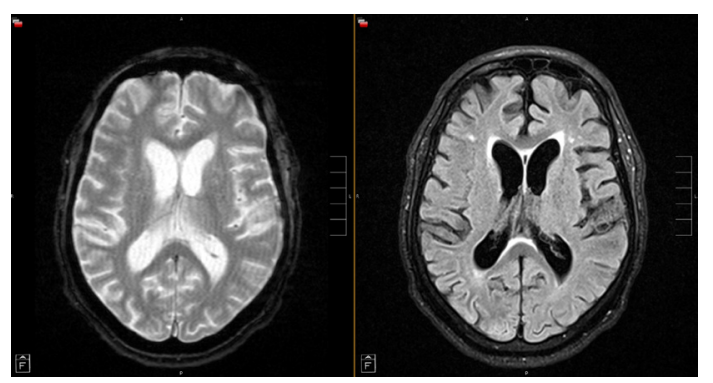

Seegobin K, Bajric B, et al. BMJ Case Rep Published Online First: [please include Day Month Year]. doi:10.1136/bcr-2017223019
CrossMark

Figure 1 Areas of hyperintense fluid-attenuated inversion recovery (FLAIR)/T2 foci noted in the superficial and deep subcortical white matter of the supratentorium.

\section{Learning points}

- West Nile virus is well known to cause meningitis and acute flaccid paralysis, but less is known about the delayed motor symptoms and clinical outcomes of West Nile fever.

- Myoclonus of the upper extremities and face can be a late presentation of West Nile infection.

- The long-term outcomes of dyskinaesias in West Nile infection are not well defined but can be favourable as in this case, with supportive care.

and was alert and fully oriented. Given the clinical picture with normal mental status and consciousness, combined with EEG and MRI, we thought it unlikely that these episodes were focal seizures. Thereafter, the patient had a steady recovery with normal mental status and motor examination.

West Nile virus (WNV), a member of the Japanese encephalitis virus antigenic complex, can lead to a variety of clinical symptoms ranging from a mild influenza-like illness to neuroinvasive disease. Advancing age increases the risk of neuroinvasive disease. ${ }^{1}$ Patients with WNV encephalitis have been reported to develop movement disorders including tremor, myoclonus and parkinsonism. ${ }^{12}$ As demonstrated, there was myoclonus of the upper extremity and facial muscles that persisted even during sleep. The sequelae and longterm prognosis of WNV infection is not well understood, but myoclonus of the upper extremities and face has been reported to persist for months. ${ }^{2}$ In this case, the motor symptoms resolved with supportive care, indicating some patients with WNV encephalitis can have a favourable course.

Contributors SM and BB provided direct patient care and conceived the idea for the report. KS and SC performed the literature search and drafted the discussion. SM and BB wrote the case report. SM and SC undertook revisions of the manuscript. All authors contributed to and approved the final manuscript.

Competing interests None declared.

\section{Patient consent Obtained.}

Provenance and peer review Not commissioned; externally peer reviewed.

(c) BMJ Publishing Group Ltd (unless otherwise stated in the text of the article) 2017. All rights reserved. No commercial use is permitted unless otherwise expressly granted.

\section{REFERENCES}

1 Petersen LR, Brault AC, Nasci RS. West Nile virus: review of the literature. JAMA 2013;310:308-15.

2 Sejvar JJ, Haddad MB, Tierney BC, et al. Neurologic manifestations and outcome of West Nile virus infection. JAMA 2003;290:511-5. 
Copyright 2017 BMJ Publishing Group. All rights reserved. For permission to reuse any of this content visit http://group.bmj.com/group/rights-licensing/permissions.

BMJ Case Report Fellows may re-use this article for personal use and teaching without any further permission.

Become a Fellow of BMJ Case Reports today and you can:

- Submit as many cases as you like

- Enjoy fast sympathetic peer review and rapid publication of accepted articles

Access all the published articles

- Re-use any of the published material for personal use and teaching without further permission

For information on Institutional Fellowships contact consortiasales@bmjgroup.com

Visit casereports.bmj.com for more articles like this and to become a Fellow 